DOI: 10.51480/1899-5101.14.1(28).6

\title{
Cultural Citizenship, Popular Culture and Gender: Examining Audience Understandings of The Handmaid's Tale in Hungary
}

\author{
Agnes Strickland-Pajtok \\ (iD) 0000-0003-2313-8275 \\ Eszterházy Károly University, Hungary
}

\begin{abstract}
This article examines how audiences engage with popular culture in ways that forge political awareness and civic engagement. Through exploring the various levels of engagement of Hungarian women with the 2017-2020 television adaptation of The Handmaid's Tale, this study answers questions such as: How do Hungarian female audiences engage with topics raised in The Handmaid's Tale? How does their engagement with the show encourage cultural citizenship? Based on in-depth interviews with twenty-two Hungarian women, this qualitative empirical research sheds light on the role of television drama series in facilitating the manifestation of cultural citizenship as an arena of identity-construction and community-formation.
\end{abstract}

KEYWORDS: cultural citizenship, feminism, television entertainment, audience studies, Hungary.

\section{INTRODUCTION}

Serial drama has proven to be one of the areas of popular entertainment with potential as an instigator of public connectivity and political engagement (see Hill 2018; Hemes \& Stello 2000; Askanius 2017; Nærland 2019). Joke Hermes (2005: 11) also argues that:

[w] hile it allows political issues to be raised, the very strength of popular culture is that it is not a manifesto. (...) It makes the presence known to those who are not in positions of direct political or economic power.

In this study, I take this perspective as a starting point to explore the social and political potential of television entertainment in engaging audiences in pressing political issues of our time. 
Based on in-depth interviews with twenty-two Hungarian women, this qualitative empirical research aims to shed light on the role of television drama series in facilitating cultural citizenship. This is understood as "an arena in which not only meaning is struggled over, but identity, subjection and subjectivity, community, and inclusion and exclusion as well" (Hermes, 2005: 6). Thus, the main motivation behind this scrutiny is to examine whether the engagement with products of popular culture can propel political interest, and to probe the statement that popular culture can be "celebrated as a domain of resistance against dominant power relations" (Hermes, 2005: 3). Here the broad topic of politics and popular culture is going to be studied through examining the political dimensions of television series, and through exploring the various levels of engagement of Hungarian women with the drama series adaptation of Margaret Atwood's book (1985) The Handmaid's Tale (HBO, 2017-2020).

The plot of the series revolves around the story of June, who tries to find her daughter who had been torn away from her, and free her from Gilead. The brutality, extreme inequality and violence of this totalitarian regime are conveyed to us through the protagonist's story, and as viewers, we are invited to identify with life in this dystopia through her eyes.

The current political developments in Hungary concerning the role of women and gender equality also make topics tackled by the drama series relevant. For instance, the declining birth rate is planned to be overturned by significant subsidies for families with three or more children (Miklós, 2015). At a 2015 party congress, László Kövér, the Speaker of the Hungarian National Assembly, stated that "the pinnacle of a woman's self-expression is to give birth" (444.hu, 2015). Also, accredited gender studies MA courses in the country were discontinued in 2018 (Balázs, 2018), and in 2020 according to new amendments to Law 2020 LXV only opposite sex couples can adopt children (Hungarian Spectrum, 2020). These incidents all suggest that for the Hungarian public - and women especially - topics connected to gender roles and the blurring of boundaries between the public and private spheres are all current and talked about, causing often heated debate regarding the social-economic impacts and ethical implications of the government's family policy (Átlátszó, 2016; Balogh, 2018; Bence, 2018).

Another, more universal reason for conducting a line of research fueled by feminist audience studies and focusing exclusively on women's opinions, was to draw attention to the well-known, oft forgotten phenomenon, that in society the norms of typical and accepted behavioral patterns for men and women are pre-set. These globally normative and widespread patriarchal societies privilege masculine behavioral patterns. This experience is in accordance with the statement by Josephine Donovan (2012: 187): 
[e]xisting patriarchal theory has no place for women as women; at best, women can be incorporated as pale reflections of men. Thus, many "gender-neutral" laws have failed to benefit women because they neglect the contingencies of most women's social situations.

A consequence of this inherent, unavoidable, yet undetectable patriarchy, is that women often feel that public life is not commensurate with their needs, and does not tackle their problems, hence they withdraw from it, and remain silent regarding public matters.

Inspired by these topics, this interview study is informed by the following research questions (RQ): RQ1 - How do Hungarian female audiences engage with topics raised in the television series The Handmaid's Tale? RQ2 - How do they react to the dystopian patriarchy portrayed in series and how does this prompt reflection on gender inequality and body politics in contemporary Hungary? RQ3 - How can we understand this engagement as expressions of cultural citizenship?

\section{CULTURAL CITIZENSHIP}

In establishing a thematic framework for this research, Joke Hermes's notion of cultural citizenship is of vital importance, since it offers the possibility to "analyze the democratic potential of popular culture" (Hermes, 2005: 4). This aim coincides with the scope of the research questions about capturing Hungarian audiences' reflections on gender inequality prompted by the series. According to Hermes's understanding, cultural citizenship is "an arena in which not only meaning is struggled over, but identity, subjection and subjectivity, community, and inclusion and exclusion as well" (Hermes, 2005: 6). This concise but dense definition aptly captures two aspects of cultural citizenship: an arena for identification and of community-building. Thus, engagement with media products is not a solitary activity, but a "process of bonding and community building, and reflection on that bonding, that is implied in partaking of the text-related practices of reading, consuming, celebrating and criticizing offered in the realm of (popular) culture"” (Hermes, 2005: 10). Scrutinizing audience-reactions can become a territory to explore one's identification processes in relation to social, political phenomena. Therefore, in this research, reactions to extreme gender inequality and patriarchy portrayed in the series mark the tendencies and peculiarities of a certain (interpretive) community.

As the research questions of this study indicate, the aim here is to capture audience-engagement inspired by the series. Yet, the scope of this engagement is somewhat vague to delineate. On one level it is clear that concrete actions (such as attending protest demonstrations, signing petitions) count as engagement, but 
it is less discernable to draw a line on the other side, and decide whether more informal acts (for instance a chat with friends) can also be defined as engagement. To find an answer to this puzzle, I share the inclusive view of Dahlgren (2006: 278) according to whom "clinging too rigidly to formal deliberation risks losing sight of everyday talk and its potential relevance for democracy". Also Dahlgren (2006: 279) argues "[t]he looseness, open-endedness of everyday talk, its creativity, potential for empathy and affective elements are indispensable for the vitality of democratic politics". Hence, the means through which popular culture can fulfill its connective position is the act talking, since it is via talk that political issues become actualized, and hence "the interactional public sphere emerge as a sector of civil society" (Dahlgren, 2006: 276).

To be able to understand the interconnectedness between popular culture and politics, a wider definition of the latter shall be accepted and used here. In everyday conversation we tend to refer to politics in its institutional sense, however, - for this research it is more fruitful to work with a broader meaning of the term. According to which, as Van Zoonen (2005: 5) contends "politics is not just what politicians do. (...) Politics is also a "field" that exists independently from its practitioners and that accommodates the continuous struggle about power relations in society". The reason for the preference for this definition is that unlike other notions, which regard the public as passive masses who are only providing the background for institutional politics, this interpretation sees people as contributors to politics, and as active agents of the public sphere. This view is in parallel with how this study understands the notion of politics, and views the connection between the public and private spheres. Dahlgren (2006: 276) also arrives at a similar conclusion regarding the porous boundaries between the private and public spheres by stating that "we have the empirical permeability between public and private (...) not least in the blending of politics and entertainment and other forms of popular culture".

Yet, in addition to overarching theoretical studies within the field of media studies, there is also a need for a wide variety of empirical inductive research which should complement abstract approaches. It should also reveal new aspects of media theory from a social, hence often more relatable perspective, and can add nuances to the field of audience studies.

Empirical studies even have the potential of highlighting alterations the genre of drama series has undergone in the last couple of decades. For instance, in her seminal study Watching Dallas published in 1985, Ian Ang gathered the most typical features of serials as displaying episodic character, 'unrecorded growth' between episodes, cliffhangers and the potential for becoming endless (Ang, 1985: 51-56). She also captured the prevailing ideology of mass culture "which arouses definitely negative associations" (Ang, 1985: 94). Even though aversion to serials can still be traced (Van Zoonen, 2005: 11), by the late 2010s the 
consumption of television series has become a socially accepted form of entertainment. As the content of television drama series often relates to "scenarios and dilemmas already of significance within broader society" (Hodkinson, 2017), popular TV-genres have transformed into "starting-points for the reflection on matters of societal or political significance" (Nærland 2019: 665).

Having read these insightful articles examining audience-engagement with popular culture, and seeking for other, even more relevant for my close field of research, a knowledge gap presented itself. For although there has been valuable research conducted in the field of audience studies in Hungary (Bényei, 2001; László, 2005; Munk, 2009), the examination of genres of popular culture from the point of view of feminist audience studies have remained understudied within the discourse of Hungarian media research. Hence, this study attempts to fill in (or at least lessen) this knowledge gap.

\section{METHODOLOGY}

This study draws on qualitative in-depth individual interviews with female interviewees ( $\mathrm{N}=22$, aged 17-56) conducted in the period of April to May 2020 in Hungary. I intended to meet personally with all of the interviewees, yet this was possible only in seven cases. Due to the COVID-19 pandemic, social distancing was enforced, and traveling was restricted, hence the rest of the interviews were conducted remotely over telephone, or via Skype, or Messenger.

Since I decided to analyze Hungarian women's reactions to and engagement with the series, non-probability purposive sampling appeared to be the right path. Within this chosen group I had no further requirements in terms of whom I intended to include in the research, hence anyone could participate regardless of age, location within the country, or how many episodes they had seen. Therefore, my data became homogenous in that regard. In terms of finding respondents, I initially confined myself to convenience sampling: I looked up friends of mine on Facebook who liked or followed the official page of The Handmaid's Tale's latest adaptation. This way I found three people who agreed to talk to me. The fourth interviewee joined through snowball sampling: one of the interviewees recommended her daughter to participate. The rest of the participants joined by responding to my call on Facebook, which I shared both on my personal timeline, and in order to find interviewees who are not my friends and acquaintances, in various Facebook groups.

The interviews were conducted in Hungarian, with the exception of Respondent 1, whose command of English was advanced due to her family's background, and hence the expression of her thoughts was not compromised despite not using her mother-tongue. The interview questions were designed to allow the participants 
to verbalize their engagement with the series, while they also encouraged participants to make connections to their own socio-political context.

Analyzing qualitative interviews often entails textual analysis as a main guiding principle. Yet, this method has its pitfalls, since textual analysis can covertly represent, as Hermes 2005: 86 argues "the researcher's (superior) reading of a set of texts against the partial or no politicized understanding of audience groups". To avoid this trap it seemed to be an advantageous step to ameliorate the hierarchical nature of textual analysis by harnessing the hermeneutic tradition, and employing the infinity of the hermeneutical circle (Kvale, 2007). When applying this tradition, I first re-listened to and transcribed all of the interviews, which provided me with an even deeper insight. I re-read the most crucial parts to allow the dynamic interplay between the individual passages and the entire text to reveal new layers of meaning. This way many contradictions of the interviews explained themselves, and answers to questions were found sometimes scattered in the text.

During the coding process I sought for reflections on the fictional world of Gilead and its characters, then expressions of engagement with the series were traced, which was later extended to reflections on inequality prompted by the series. By close reading of the results, the following thematic clusters were formed: 1) Comparison of Gilead and their context; 2) Engagement with the series manifesting in active civic participation; 3) Factors derailing manifestations of cultural citizenship, and leading to civic disengagement. Although a hermeneutic process is infinite, here it ended when a sensible coherent meaning was reached (Kvale, 2007).

Since the interviews were recorded in Hungarian, the relevant parts needed to be translated into English. All in all, this experience supported the assumption that although audience research is not easily combined with textual analysis (Hermes, 2005), if applied sensibly this combination can lead to rewarding results.

\section{FINDINGS}

To find answers to RQ1-3, as presented earlier, the interview questions were designed not only to reveal reactions given to the characters and their plotlines portrayed in The Handmaid's Tale, but also to capture articulations of the participants' identity-construction prompted by the program. The participants were encouraged to employ a certain suspense of disbelief, and to view the world portrayed in The Handmaid's Tale from within, as if they were part of the story, and not as a media product. In this way, the questions should elicit spontaneous reactions and preferences as opposed to premeditated answers. 


\section{PARALLELS BETWEEN GILEAD AND THE WORLD WE LIVE IN}

To guide the participants towards discussions of socio-political topics, they were asked whether they see any parallels between the fictive Gilead and "our world." The reason for this choice of words was to make the interviewees free to associate Gileadean patterns to their micro or their macro (national or even international) contexts. Thus, a wide variety of similarities were enumerated.

One of the most commonly mentioned parallels identified by the respondents was the overarching feeling of mistrust.

Respondent 5: "They [the handmaids] don't dare to say even obvious things aloud, which are in everyone's minds, they are just carefully testing who they can trust and who they can't".

To underscore these thoughts, during the interviews a similar reluctance to verbalize concrete beliefs was also palpable. Hesitation was often expressed through non-verbal communication by glancing at the recording device, slowing down of speech delivery, asking permission or expressing doubt: Respondent 5: "I don't know if I'm allowed to say this".

However, even though many participants concretely expressed reluctance to talk about politics, most of them eventually acted otherwise, and after an initial hesitation discussed political issues lengthily. A statement that captures this ambiguous attitude to politics was uttered by one of the respondents: "I think - but I don't want to talk about politics - in Hungary today there is no democracy" [Respondent 8]. In another interview of a similar structure, the interviewee's hesitation was followed by a well-formed opinion:

Respondent 22: "I don't want to talk about politics, but in the recent past there was a scandal when certain politicians and the government suggested that a woman has to have three children, and these statements make us, women feel that those men, up there in the Parliament want to decide what shall happen to our bodies".

These statements suggest that in addition to capturing reactions and preferences, popular culture often provides the audiences with topics in connection to which they are willing to express their opinions and their political beliefs. This finding underscores Dahlgren's (2006: 276) statement that "popular culture helps people to connect the private and the public, the personal and the political". As in these cases - through the mediating subject of The Handmaid's Tale's fictional events - these Hungarian women were eventually willing to talk about socio-political topics, and verbalize their objection to gender inequality, patriarchy and totalitarian regimes. These participants were not characterized by the customary 
Hungarian political apathy (Timar \& Republikon Institute, 2017), as despite their initial reluctance they engaged in discussing political issues. This lack of apathy strengthens the assumption that popular culture can be more than mere entertainment, and emerge as a sphere of "interpretation and evaluation and the space to be excited, frightened, enthralled" (Hermes, 2005: 10).

Motherhood, and the appearance of the female body as a common commodity of the state of Gilead were echoed frequently in the interviews. This circumstance reminded some participants of their own maternity.

Respondent 22: "When I was pregnant I was bothered by the hype and admiration, because I felt that it was not because of myself, but only because of the baby. That I'm only wanted because I'm pregnant".

Another similarity between Gilead and our present day experience identified by the respondents is the way women are treated while giving birth; Respondent 18: "in hospitals women are extremely vulnerable, you're forced to accept everything, they say that it is the child's life which ultimately matters". One participant went as far to say that the similarity between Gilead and her experiences is that in both worlds "women are machines for giving birth" [Respondent 7].

However, although most participants see the parallel between the attitude to women and childbirth in Gilead and present day Hungarian governmental decisions, this is not necessarily a negative trait for everyone. For instance, one respondent admitted that despite the similarities, she thinks that their current manifestations should be welcomed, since in Hungary this ideology:

Respondent 15: "doesn't appear in such a sick way. Rather that women are encouraged to opt to have more children, one, two, three, four, as many as one wants, not every woman has to have a career".

While processing the plethora of answers, it was especially thought-provoking to witness how the interpretation of this media product happens through one's own personality and world view. To provide evidence to this observation, while most respondents notice the extreme inequality the series portrays, these episodes conjure very different associations in them. Some are reminded of present day gender inequality; "women still earn less than men, which is also a form of discrimination" [Respondent 10].

Some associated the dictatorial regime of Gilead with historical events of the past by stating that "there could be many similarities including the events during World War II and communism" [Respondent 6]. The current socio-political climate in Hungary also seemed reminiscent of those in Gilead for a few of the respondents: 
Respondent 7: "it is an existing problem in current politics (...) that we don't expect anything else from women just to give birth. This has been stated clearly, and our welfare system is based on this".

Yet, during the interviews the scope of attention occasionally went beyond the borders, and the issue of global inequality was also raised:

Respondent 15: "as we can see, the pillars of the world work that way that there are extremely wealthy countries, but this is only possible because there are very poor ones. (...) So, there shouldn't be famine, but there are countries where they gobble more than they can eat".

Also the inherent hierarchy of religious communities was mentioned: gender inequality "is typical at Christians and Jehovah's as well. I'm saying that as being a Catholic. (...) There are no female priests in the Catholic church" [Respondent 18]. These different perceptions of the same media product suggest that one's interpretation of works of art is guided and transformed by one's own experiences, knowledge, cultural and social background.

Apart from political parallels, more universal ecological-biological similarities were also noted. In Gileadean society, one of the key problems which fuels its radical (and desperate) dictatorial and patriarchal regime, is environmental pollution and the rapidly declining birth rates. Some interviewees see such correspondences with our lives, where "the number of barren women are also increasing” [Respondent 12]. Environmental concerns connected to bodily issues were also voiced: "mankind is not doing well regarding looking after their natural habitat. (...) We can feel that women have more and more physical difficulties [to conceive]" [Respondent 5].

\section{CULTURAL CITIZENSHIP AND CIVIC PARTICIPATION}

A key aim of this research was to reveal more about the various levels of engagement of the audience with the program, and to find out how they react to the patriarchy shown in the series, and how the program prompts reflections on present day issues in Hungary. Responses to this query were usually articulated by the respondents when explaining how they would behave in a dictatorial world like Gilead, and how they respond to every day inequality.

Some thought it essential to demonstrate active civic responsibility. The actions these interviewees do, in order to attempt to induce change, include signing or setting up petitions [Respondent 21], participating in protest demonstrations [Respondent 21], raising awareness to participate in elections [Respondent 20], and write articles about pressing issues [Respondent 20]. 
In this sample even the socially-politically more active interviewees questioned the efficiency of democratic acts (like voting, signing petitions), but they would not cross the line towards illegitimate actions. Yet, occasionally the limitations of democratic institutions and practices were verbalized: "social initiatives can only be successful if they grow into demonstrations or even into a revolution which can bring forth real change" [Respondent 20].

Respondent 3 gave an intriguingly self-reflexive description of her engagement. She revealed that the series does not motivate her to carry out certain actions, but it stops her from acting a certain way. By becoming more perceptive to gender inequality she consciously focuses on avoiding situations - such as being humiliated, lacking equality, suffering mental and physical abuse. Respondent 3 also aims to put an end to these kinds of incidents both for herself and for women around her. Gaining inspiration from the series is not unique to her, finding encouragement in fiction was mentioned by other respondents. For instance:

Respondent 19: "That's why it is good to watch the series (...) If you get into similar situations, for example, if you are treated unfairly, then you can find strength in what you have seen".

Another way to act against harmful behavioral patterns seems to lie in the domain of child rearing. When talking about how to implement change and work towards gender equality, a significant number of the interviewees said that they consciously raise their children according to a less conventional, less patriarchal set of rules. This idea appeared regardless of whether the respondents were raising female or male children, yet those who were talking about boys, men of the future, seemed to be even more devoted. For instance:

Respondent 22: "It is very important for those who have sons like me, that we raise them that way that they won't think when they come home from work that they have done all their duties".

In the case of girls, the intent to protect them, and keep them away from negative experiences is usually more dominant. "I have two daughters and I always pay attention that they don't have to go through what I had to" [Respondent 21]. Intriguingly the power of education always appeared in discussions with participants who are teachers or lecturers, who often displayed a sense of devoted optimism. These interviewees did not follow June's overtly rebellious methods, rather the covert strategies of the Marthas, who would rather choose the strategy of undermining the system from inside, and believe that their role as teachers also entails the responsibility to make younger generations aware of the importance of equality and standing up for basic rights. "As a lecturer our position 
is quite good. Because we can encourage students to think critically and to stand up for themselves" [Respondent 6]. Another sense of teachers' duty appears in Respondent 4's thoughts:

Respondent 4: "[If I were in Gilead] I would save those who are rebelling. (...) But actually this is what I'm doing now, I'm saving those who are rebelling. That's why I work in teacher training".

Even though, as we have just seen, there were many examples of concrete engagement, some more subtle forms of participation were also noticeable. Almost all participants recalled that they first heard about the series through someone recommending it to them. Respondent 12: "Once I was at one of my friends' place, and she recommended it [The Handmaid's Tale]. I watched the first episode with her, and then I started to watch it on my own".

In addition to recommending it, discussing issues related to the series with friends, family members or online social media groups is also typical. These discussion topics include male-female roles, raising children to be aware of patriarchal patterns and plans to change a flawed system. As the following respondent (the youngest participating in the research) shares:

Respondent 1: "As a teenager I don't really have the means to stand up. But I do like to talk about it with my friends, my female friends and just get their opinions on what they think of the society, and what we could do in the future as well".

Respondent 2 shared the experience of watching the series with her sister, with whom they often dwell on the horrors the program displayed. Another interviewee shared the experience of the series with her daughter: "My daughter - 11 at the time - watched a few episodes of the series with me, (...) and we discussed how women are silenced in the series" [Respondent 5], thus highlighting that talk is a "constitutive of publics and is thus both morally and functionally vital for democracy (Dahlgren, 2006: 277). Through these accounts it can also be witnessed how audiences shape their identities and simultaneously bond through capacity of television entertainment to launch a dialogue about crucial matters. When offline dialogues are not possible, discussions often take place online, either in various social media groups or on one's own timeline: "Interesting that I posted about The Handmaid. If something is like wow!, then I immediately post about it on Facebook" [Respondent 9]. These statements display the potential of popular culture to not only amuse its audiences, but also to become "a means of understanding society and social relations" (Hermes, 2005: 158). 
The articulations of community and bonding expressed by respondents in this study pay testimony to how TV series and other popular genres can facilitate dialogue especially regarding 'sensitive' topics, which divide society such as power inequality, corruption, and the question of women's roles in reproducing the nation. Contemporary Hungarian society is deeply divided by party preference with no dialogue between the two sides. The Handmaid's Tale - along with other drama series - has the potential to catalyze discussions between the two groups about topics which they usually avoid and to forge various forms of engagement. The mobilization of curiosity to initiate discussion with people of opposing opinions suggest that readers indeed "may use their knowledge of particular subgenres or authors to communicate with others, and thereby build the community itself in its most concrete forms" (Hermes, 2005: 68).

Based on these accounts, the assumption is formed that the experience of watching the program provides audiences with a sense of community, imagined or real, online or offline, thus manifesting the essence of an interpretive community (Hermes, 2005: 155). The constituents of a particular interpretive community are "shared knowledge of the history of the subgenre, the building of virtual texts, and the ability to use one's knowledge of this form of popular culture to communicate and make contact with others" (Hermes, 2005: 68). Through analyzing the interviews, it can be seen that all three factors materialize in this research. First, the viewers have a thorough understanding of the genre in general, in which they can place The Handmaid's Tale. Secondly, they have their own individual reading of the tale. Thirdly, they are also capable of implementing this covert knowledge in their real life activities, as we have seen when they spoke about engaging with others and engaging with socio-political topics. Thus, due to the formation of an interpretive community "a particular form of cultural competence may be seen as a bond between groups of readers who never meet physically" (Hermes, 2005: 67). Therefore, the participants' attempts to position themselves as members of the imagined audience of The Handmaid's Tale, and also as members of their socio-political context while also probing its prevailing norms, delineate patterns of cultural citizenship "as a domain in which we may question how we belong to society" (Hermes \& Stello, 2000: 230).

It is also a common feature of the participants that they often questioned the importance of their own actions. They often claimed that as individuals they are "too small" to act and induce change. Yet, when asked what they would do to stop inequality, they often describe actions similar to those of grassroots movements, in the sense that the participants often revealed that they make "efforts to mobilize individuals to take some action often of a political nature" (Kaid \& Holtz-Bacha, 2008). Even recommending either or both the book and the series to others, or getting involved in online or offline discussions about topics suggested by the series and sharing the knowledge and experience of the narrative 
with others can be seen as an act of bottom-up social activism. Nevertheless, for a few interviewees, social activism is a conscious choice, motivated by the belief that imposed top-down initiatives are less efficient then those when individuals can act in "their own context, where they can still rely on their own personal ties and connections" [Respondent 5], and when they can "help and induce change within their own context" [Respondent 20]. These statements capture grassroots activities as initiatives and movements coming from "the people: ordinary men and women, who autonomously organize themselves to cope with their predicaments" (Esteva, Shiva \& Prakash, 2014: 3).

However, it is necessary to see that the actions and thoughts materializing after watching the series were merely conjured by the media product, but not created by it. As Respondent 3 observed: these feelings were inside her, only watching The Handmaid's Tale brought them to the surface. Hence, we can assume that watching the program does not alter fundamentally the interviewees' core beliefs and thoughts. Rather, watching the series heightens existing feelings, and legitimizes frustrations felt over social inequality. In these cases the emotions invoked by the TV program are turned into fully formed thoughts and get integrated into the respondents' world-view. Thus, these interviews provide us with examples about the assumption that media texts can indeed shape one's identification processes, and spectatorship can be "conceived as a set of subject positions constructed in and through texts" (Ang, 1996: 112).

\section{CAUSES OF DISENGAGEMENT}

Even though audiences display different levels of engagement with the television production of The Handmaid's Tale, a tendency can be seen that when respondents talk about the scope of their real-life actions prompted by the program, they often describe reasons why they often fail to act against injustice. When analyzing results about methods of withstanding inequality and injustice - both hypothetically in Gilead and in real life, the phenomenon can be traced among interviewees that they are often aware of right actions and choices, but various feelings and forces hinder their actions. In this research, the background of these restrictive forces are quite heterogeneous, hence to make them more comprehendible they are organized here into four categories.

Fear is one of these forces, which stops them from acting against injustice. Intriguingly, this sense of intimidation increases according to the level of one's professional position. Employees and blue collar workers experience a bigger sense of freedom, and feel that they would always stand up against oppression. In their case, examples of injustice often come from their own lives, and are usually of a personal nature. On the other hand, those in leadership positions feel that their freedom to express their views is limited. 
Respondent 12: "Probably I shall voice my opinion more that I do.

Interviewer: And what stops you?

Respondent 12: "Mostly, political fear. That as a leader I can't say things the way I really think about them".

Or in another case: Respondent 17: "[O]ne is scared to act, because of their work. What will the people say? And things like that."

Apart from fear for oneself, the fear or even the potential threat against one's offspring is also a significant force to make one collaborate and withhold one's opinion. Those respondents who have children, shared the feeling that they would be braver, and more active politically and socially had they not been mothers: "If I didn't have anything to lose, and if I didn't have to have my children in mind" [Respondent 5]. One woman even went as far as saying that "children are biological weapons" [Respondent 4]. As an explanation she added: "[T] hrough her children, a woman becomes vulnerable. Hence, women who want to stay independent do not have any children" [Respondent 4].

In addition to political issues, the other dominant force stopping women from acting, seems to be a social one of deeply ingrained gender norms. Due to these norms, women are often complicit in maintaining an authoritarian patriarchal system, and prevent other women from displaying unconventional behavioral patterns. Typically and somewhat paradoxically, mothers - out of good will often encourage their adult daughters to act according to the perceived rules of patriarchy:

Respondent 19: "My mother often says that sometimes one has to give in, and sometimes I shall give in too. And then I say OK, OK, but what if I know that I'm right?" Or in another episode from the same mother-daughter relationship: "These days my mother often says that I shall be more humble. But actually I think I'm humble enough.”

The gender norm that a wife shall please her husband with her appearance can still be seen, though not so much according to the interviewees' views, but according to those of their mothers:

Respondent 22: "If I have my hair cut then my own mother asks immediately whether my husband likes it. And if I say yes, then she says: that's the most important. But no, what is important is whether I like it or not".

Interestingly, the conservative suggestions of mothers usually meets with their daughter's disapproval and dismissal, which might suggest that even 
though patriarchy is still dominant, a slight shift towards a more liberal order has started to appear.

A less benevolent, but similar behavior is that of the female leader. The experience is often shared that "if women become leaders they take up masculine behavior patterns, and they are not very tolerant with women" [Respondent 20]. In the series, Aunt Lydia is the character, who embodies this type of female leader. The opinion on her was not favorable because she turned against and betrayed women. Yet, some of the interviewees have either read The Testaments or heard about its storyline concerning Aunt Lydia starting to subvert the system from within, and they tended to see her character in a more positive light.

The experience of the masculine female leader is not rare. Once women are in a leadership position instead of displaying compassion and encouragement often the opposite happens, and intolerant, insensitive behavior is acquired (Margit, 2002). This study does not have the scope to trace the background and motivation for this behavioral pattern, yet we can assume that the lack of female leader role-models also contributes to this. For instance, in Hungary "[i]n the sub-domain of social power, Hungary has the second lowest score in the EU. There are no women on the boards of research funding organisations. Women comprise $29 \%$ of board members of publicly owned broadcasting organisations and only $10 \%$ of board members of the highest decision-making bodies of national Olympic sports organisations" (Gender Equality Index, 2019). Also, a traditional patriarchal system still prevails, which privileges masculinity, "which marginalizes not only women but also feminine qualities expressed by men" (Duvall, 2012: 267), thus enhancing competitiveness, intolerance, and authoritarianism.

It seems challenging to arrive at an overarching conclusion regarding factors, which curb one's willingness to rebel. However, maybe this heterogeneity can provide us with an answer, and a surprising discovery: it has been clear and expected that an authoritarian regime can stop its underprivileged citizens from acting and standing up against injustice. But what is more baffling is that ingrained gender norms, which exist unnoticed, also do just as much harm, since they enforce the rule that "public discourse requires the exclusion of femininity and women" (Donovan, 2012: 187). Hence, it appears from this research that all the listed factors: the existential and social threat, the fear for one's children, and a prevailing patriarchy often upheld by other women, all contribute to the same phenomenon, the maintenance of the traditional silence of women. 


\section{CONCLUSIONS}

One of the key intentions of this article was to explore particularities of Hungarian female spectatorship. When analyzing the interviewees' responses to The Handmaid's Tale's fictional world and the associations it triggered, it became visible that participants often revealed a shared knowledge of Hungarian gender-related expectations, current issues of family politics and history. From these reactions, it can be gleaned that for this particular interpretive community the experience of a child-centric and conservative political discourse is common. However, the ways interviewees reacted to these experiences were diverse. These heterogeneous responses also drew attention to the potential of popular television to emerge as a suitable arena for socio-political discussions. This is achieved through several features. Primarily, the distinct characters' experiences and intriguing plotlines. There are also abstract notions of politics (such as dictatorship, freedom of speech, family politics), which become tangible, hence providing the viewers with vicarious experiences, and examples of injustice, which can facilitate audiences to measure their world against the fictional one. This kind of engagement with the TV series prompting cultural citizenship as a continuous re-construction of one's identity, also resonates with Ang's (1996) situational and particularist view of gender identity, which is considered "ambiguous and incoherent, permanently in process of being articulated, disarticulated and rearticulated" (Ang, 1996: 125).

The silence, withdrawal and mistrust of the handmaids in the television series were often associated by the interviewees with everyday experiences of present-day Hungary. Participants revealed that they often stay silent and do not act against injustice because of political fear for themselves or their family members. Even though the respondents' withdrawal from the public sphere appears as an act of civic disengagement, the admission of this decision still shows political consciousness: through displaying a self-reflexive attitude and acknowledging passivity, they mobilized their political awareness. Thus, paradoxically, the act of admitting political passivity and intimidation became a manifestation of cultural citizenship. Therefore, the reluctance of women to discuss politics during the interviews, is not a marker of neglect or ignorance, but a sign of their distrust towards the dominantly masculine structures of the current authoritarian regime.

If we attempt to conclude these results of cultural citizenship through the lens of feminism, the answers seem somewhat controversial. The ambiguous findings that Hermes and Stello (2000) reveal about the feminism's relationship with cultural citizenship through the engagement of crime reading audiences, also hold for audiences of The Handmaid's Tale: 
[i]n how readers are constructed as economic and political subjects there is evidently enough space for them to find cracks in dominant culture to build sustaining identities and critical forms of empowerment, that paradoxically result in continuing allegiance to that system. (Stello, 2000: 230)

When analyzing the responses of the study's Hungarian women, the same paradox is revealed. Through the different manifestations of engagement, critical identities are constructed along with interpretive communities, yet these constructs - at the moment - are not subversive, and still contribute to the maintenance of the status quo.

Nevertheless, we can witness that popular culture can indeed become the stepping stone between the political and the private spheres through adapting social matters into narratives which are digestible for larger audiences, and making the otherwise seemingly remote political issues relatable to one's private experiences. In the case of The Handmaid's Tale, we can witness the phenomenon of the series providing a context for Hungarian women to contemplate on concepts of social and gender inequality and the right to one's body. Thus through discussions taking place in informal online and offline groups, the TV series formed an environment, which facilitates the appearance of citizenship.

\section{ACKNOWLEDGMENTS}

I would like to thank Dr Tina Askanius at Malmö University for her invaluable comments and suggestions.

\section{REFERENCES}

Ang, I. (1996). Living Room Wars. London: Routledge.

Ang, I. (1985). Watching Dallas: Soap opera and the melodramatic imagination. Translated by Della Couling. London: Routledge.

Askanius, T. (2017). Engaging with The Bridge: Cultural citizenship, cross-border identities and audiences as 'regionauts'. European Journal of Cultural Studies, 22(3): 271-290.

Átlátszó (2016, January 7). CSOK-os otthonteremtés csak fehérgallérosoknak. Retrieved February 27, 2021 from https://igyirnankmi.atlatszo.hu/2016/01/07/csok-os-otthonteremtes-csak-fehergallerosoknak.

Balázs, P. (2018, October 16). A kormány hivatalosan is megszüntette a gender szakokat [The Government Has Officially Abolished Gender Courses]. Index.hu. Retrieved February 21, 2021 from https://index.hu/belfold/2018/10/15/a_kormany_hivatalosan_is_megszuntette_a_gender_szakokat/. Balogh, E. S. (2018). Home savings accounts. Hungarian Spectrum. Retrieved February 21, 2021 from https://hungarianspectrum.org/tag/home-savings-accounts/. 
Bence, H. (2018). Kapkodva vezették be a CSOK-ot, az egy és két gyerekes, fiatal házasoknak csak nehezebb lett tőle a lakáshoz jutás [CSOK was introduced in a hurry, making it harder for young couples with one of two children to get the apartment]. 444. Retrieved February 21, 2021 from https://444. hu/2018/02/21/kapkodva-vezettek-be-a-csok-ot-az-egy-es-ket-gyerekes-fiatal-hazasoknak-csaknehezebb-lett-tole-a-lakashoz-jutas.

Bényei, J. (2001). Az Alkonyzónától a Simpson családig [From The Twilight Zone to the Simpson Family]. Médiakutató. Retrieved February 21, 2021 from https://mediakutato.hu/cikk/2001_02_ nyar/06_alkonyzona.

Donovan, J. (2012). Feminist Theory. Continuum.

Dahlgren, P. (2006). Doing citizenship. European Journal of Cultural Studies, 9(3): 267-286.

Duvall, S. (2012) Patriarchy In: Encyclopedia of Gender in Media, SAGE Publications.

Esteva, G., Prakash, M. S., \& Shiva, V. (2014). Grassroots postmodernism remaking the soil of cultures. Zed Books.

Gender Equality Index 2019: Hungary. European Institute for Gender Equality. Retrieved April 9, 2020 from https://eige.europa.eu/publications/gender-equality-index-2019-hungary.

George, K. (2012). Self-help as women's popular culture in suburban New Jersey: An ethnographic perspective. Participations: Journal of Audience \& Reception Studies, 9(2), Retrieved April 9, 2020 from https://www.participations.org/Volume\%209/Issue\%202/3\%20George.pdf.

Hermes, J. (2005). Re-reading Popular Culture: Rethinking Gender, Television, and Popular Media Audiences. Blackwell Publishing.

Hermes, J., \& Stello, C. (2000). Cultural citizenship and crime fiction. European Journal of Cultural Studies, 3(2): 215-232.

Hill, A. (2018) Saga's story: Emotional engagement in the production and reception of Nordic crime drama The Bridge. In: Turnbull S., Peacock S. \& Hansen KT (eds.) Crime Pays - Contemporary Television Crime Dramas, Palgrave Macmillan.

Hodkinson, P. (2017). Media, culture and society: An Introduction. Kindle Edition.

Hungarian Spectrum (2020, November 14). Anti-Gay-Lesbian Amendments to the Adoption Law. Retrieved February 21, 2021 from https://hungarianspectrum.org/2020/11/14/anti-gay-lesbianamendments-to-the-adoption-law.

Kaid, L. L., \& Holtz-Bacha, C. (2008). In Encyclopedia of political communication. Sage Publications.

Kvale, S. (2007). Qualitative Research kit: Doing interviews. SAGE Publications.

Margit P. (2002). A nők reprezentációja [Representation of Women], Médiakutató. Retrieved April 9, 2020 from https://mediakutato.hu/cikk/2002_03_osz/06_a_nok_reprezentacioja.

Miklós, J. (2015, December 21). Összeszedtünk tíz fontos kérdést az ingyen 20 millióról [we’ve compiled ten important questions about 20 million]. Retrieved April 9, 2020 from https://index.hu/gazdasag/2015/12/16/csok/.

Munk, V. (2009). Sztárság, elméletben. Médiakutató. Retrieved April 9, 2020 from https://mediakutato. hu/cikk/2009_01_tavasz/01_sztarsag_elmeletben.

Nærland, T. (2019). Fictional Entertainment and Public Connection: Audiences and the Everyday Use of TV-series. Television \& New Media, Vol. 20 (7): 651-669. 
444.hu (2015, December 13). Nem akarunk genderörületet [We don't want gender madness]. Retrieved April 9, 2020 from https://444.hu/2015/12/13/kover-nem-akarunk-genderoruletet.

Timar, B., \& Republikon Institute (2017, August 7). A New Hungarian Political Force Sets Out to Complete the „Real Change of the Regime”. 4Liberty.eu. Retrieved April 9, 2020 from http://4liberty.eu/a-newhungarian-political-force-sets-out-to-complete-the-real-change-of-the-regime/.

Van Zoonen, L. (2005). Entertaining the Citizen. Rowman \& Littlefield.

\section{APPENDIX I.}

List of participants

\begin{tabular}{|c|c|c|}
\hline & Age & Profession \\
\hline Respondent 1 & 17 & high school student \\
\hline Respondent 2 & 23 & university student \\
\hline Respondent 3 & 46 & PR consultant \\
\hline Respondent 4 & 56 & university instructor \\
\hline Respondent 5 & 41 & lawyer \\
\hline Respondent 6 & 45 & university lecturer \\
\hline Respondent 7 & 36 & office worker \\
\hline Respondent 8 & 35 & secretary \\
\hline Respondent 9 & 55 & nurse \\
\hline Respondent 10 & 34 & office worker \\
\hline Respondent 11 & 46 & teacher \\
\hline Respondent 12 & 43 & head of education \\
\hline Respondent 13 & 38 & office worker \\
\hline Respondent 14 & 26 & beautician \\
\hline Respondent 15 & 43 & political advisor \\
\hline Respondent 16 & 38 & kindergarten teacher \\
\hline Respondent 17 & 45 & teacher \\
\hline Respondent 18 & 25 & waitress \\
\hline Respondent 19 & 27 & PhD student \\
\hline Respondent 20 & 46 & critic \\
\hline Respondent 21 & 29 & environmental manager \\
\hline Respondent 22 & 28 & office worker \\
\hline
\end{tabular}

